\title{
Radial Variation in Tracheid Lengths in Dominant Trees of Selected Coniferous Species
}

\author{
Ewa Fabisiak, ${ }^{\text {a }}$ Beata Fabisiak, ${ }^{\text {b, } *}$ and Andrzej Krauss ${ }^{c}$ \\ The radial variation was examined for tracheid lengths of Norway spruce \\ (Picea abies (L.) Karst.), European larch (Larix decidua Mill.), and Scots \\ pine (Pinus sylvestris L.) wood from dominant trees coming from an even- \\ aged stand, and growing under identical forest site and climatic conditions. \\ The measurements were completed on macerated material. The variation \\ of tracheid lengths in annual rings from the core to the bark was used for \\ determination of the border between the juvenile and mature wood in the \\ trunk cross-section. The boundary age between the juvenile and mature \\ wood zones established for the examined species was comparable, as it \\ was 25 annual rings for Scots pine and 29 for European larch and for \\ Norway spruce. In the juvenile zone, the tracheid lengths increased 2.2- \\ fold in Norway spruce wood, while in Scots pine and European larch wood \\ it was approximately 1.7 -fold. By contrast, in the mature wood zone the \\ tracheid lengths was stabilized at a certain level, showing slight \\ fluctuations. The differences in the tracheids length of early and late wood \\ in the examined annual rings were also determined, and it was established \\ that for the majority of annual rings they are statistically significant \\ $(p<0.05)$.
}

Keywords: Tracheid lengths; Early wood; Late wood; Scots pine; Norway spruce; European larch; Juvenile wood; Mature wood

Contact information: Poznan University of Life Sciences, ul. Wojska Polskiego 28, 60-637 Poznan, Poland; Faculty of Wood Technology; a: Department of Wood Science and Thermal Techniques; $b$ : Department of Furniture Design; c: Department of Woodworking Machines and Fundamentals of Machine Design;

*Corresponding author: beata.fabisiak@up.poznan.pl

\section{INTRODUCTION}

The properties of any given material are determined by its structure. For wood, its parameters depend both on the microscopic (i.e., the shape and dimensions of cells) and the submicroscopic structure (the layer structure of the cell walls), the distribution of basic chemical compounds (within particular wall layers), as well as the specific gravity (of the wood substance packing in the unit volume). Due to the structural variability of wood (both inter- and intra-species) its properties have been observed to fall within a wide range of values. Despite the considerable variability in its characteristics, wood is a valuable structural material that is also used as a raw material for the manufacture of wood-based boards and for the pulp and paper industry (Corson et al. 2004; Cloutier et al. 2007; Almeida et al. 2016).

One of the features of wood microstructure that directly affects the quality of final products, whether manufactured from solid wood or from pulp, is the length of the cells. This parameter is frequently used to identify the juvenile and mature wood zones at the cross-section of both hardwood and softwood species (Helińska-Raczkowska and Fabisiak 1991; Zhu et al. 2000; Ferreira et al. 2011; Mvolo et al. 2015a; Palermo et al. 2015; Gogoi 
et al. 2018). In deciduous species, the diameter of the vessels is often used for this purpose (Helińska-Raczkowska and Fabisiak 1999; Bao et al. 2001). Juvenile wood (JW) is formed in the conditions of the apical meristem influence on the cambium. As the crown rises upwards, this influence (of auxins mainly) on the further parts of the tree ceases and the mature wood (MW) is formed. Some authors call the juvenile wood "crown wood" because it is produced within a living crown (Larson 1962; Larson 1994; Zobel and Buijtenen 1989; Kuprevicius et al. 2013).

The determination of the width of the juvenile wood zone is crucial for industrial practice, because softwood cells coming from these annual rings may be as much as 3- to 4-fold shorter than those in mature wood (Mvolo et al. 2015b). Moreover, juvenile wood of softwoods contain a relatively low number of late wood cells, while a high share of thinwalled cells causes low density and thus low mechanical strength in this wood compared to mature wood (Koubaa et al. 2005; Severo et al. 2012). The width of the juvenile zone and duration of its formation time are dependent on many internal and external factors. These factors include genetic factors, growth rate of trees, habitat or forest site type, cambial age, geographical location, as well as the biosocial position of tree in the stand (Zobel and Spraque 1998; Bao et al. 2001; Passialis and Kiriazakos 2004; Gapare et al. 2006; Boruszewski et al. 2017). When compared to mature wood, juvenile wood is characterized by a greater lignin and hemicelluloses content at a lower cellulose content (Gierlinger and Wimmer 2004; Rowell et al. 2005). In juvenile wood, the angle of microfibrils in relation to the longitudinal cell axis in the S2 layer of the secondary cell wall is greater in comparison to that in mature wood (Fabisiak et al. 2006; Wang and Stewart 2012; Hayatgheibi et al. 2018). The mechanical properties of wood are strictly correlated with the value of that angle (Mott et al. 2002). A wide microfibril angle indicates lower strength properties of wood (Downes et al. 2002), while it also results in a high rate of longitudinal shrinkage of wood and a respectively lower tangential and radial shrinkage of wood (Dumail and Castera 1997; Donaldson 2008; Ivković et al. 2009). The presented differences in the properties of juvenile and mature wood cause a heterogeneity of wood raw timber, and changes in sorption and thermodynamic properties (Esteban et al. 2015) and the problems posed by the use of juvenile wood, particularly as a structural material (Wu et al. 2018). However, it is generally acknowledged that juvenile wood may be used to manufacture paper of a high quality. Corson et al. (2004) are of an opinion that the differing properties and strength parameters of pulp obtained from juvenile and mature wood result from the fact that the thinner cell walls in juvenile wood promote greater packing of fibers, leading to increased paper density (reduced porosity) and thus enhanced smoothness and improved optical properties. On the other hand, short tracheids were found to have a negative effect on the tear resistance of paper (Semen et al. 2001).

Variation in cell length as well as other wood properties is related to the broadly understood character of the habitat or forest site type, climatic conditions, or biosocial class of tree in the stand and density of the stand (Alteyrac et al. 2006). In even-aged stands, the general canopy is not in one plane, because as a result of a different growth rate of trees, some of them have crowns located higher, while others lower. In dominant trees, crowns receive full light from above and partly from the sides and extend above the general level of the crown cover. The dominant trees are the largest in terms of height, breast height diameter and size of the crown, compared to suppressed trees, the lowest, with the smallest crown and breast height diameter. This internal height variation of trees is of great importance for the silviculture and also has an impact on the properties of the obtained wood raw material (Assmann 1970; Mansfield et al. 2007). 
It may be concluded from past studies that environmental conditions have a greater effect on the structure of annual rings, and thus the width of the juvenile wood zone, than genetic factors (Zobel and Jett 1995; Kijidani et al. 2014; Cameron et al. 2015; Fernandes et al. 2017).

The aim of this study was to determine radial variation in tracheid lengths and to establish the boundary between juvenile and mature wood at the stem cross-section. The differences in the tracheids length of early and late wood in the examined annual rings of each species were also determined. Wood was gathered from trees of selected coniferous species that were from an even-aged stand, the same biosocial class of tree position, and grew under identical forest site and climatic conditions. This research specified the width of the juvenile wood zone in the examined species, which together with data on other wood properties (Czajka and Fabisiak 2016) provided insight into the technical quality of timber from a given geographical region.

\section{EXPERIMENTAL}

\section{Materials and Methods}

The tested material was comprised of wood from Norway spruce (Picea abies L. (Karst.), Scots pine (Pinus sylvestris L.), and European larch (Larix decidua Mill.). The tests were conducted on wood from the class of dominant trees aged 104 to 106 years. The stand was located in the Łopuchowko Forest Division, in the commune of Murowana Goślina (Poland) (52 $\left.26^{\prime} \mathrm{N}, 1^{\circ} 43^{\prime} \mathrm{E}\right)$. Three trees of each species were selected for analyses. Next, approximately 5-cm-thick test discs were cut out at the diameter at breast height and then approximately 4-cm-wide slats were cut out from the discs along the northsouth radius. It was decided to determine the width of the juvenile wood zone based on radial variability of tracheid length. These measurements were recorded for the following annual rings: $3,6,9,12$, and 15 , and next at every $10^{\text {th }}$ ring up to the bark. In order to prepare samples for tracheid length measurements in experimental annual rings, early and late wood were collected separately and next they were subjected to tissue maceration. For this purpose, a mixture of acetic acid and hydrogen peroxide at a 1:1 ratio was used. Maceration was run at a temperature of $60{ }^{\circ} \mathrm{C}$ for $24 \mathrm{~h}$ (Yang et al. 2016). In each tested annual ring, the lengths of 30 tracheids were measured in each early and late wood. Various measuring techniques are used to determine the tracheids length (e.g. Mvolo et al. 2015b; Bouslimi et al. 2019). In this work the microstructure of the wood was examined under a light microscope coupled with a computer image analyzer using the Motic Images Plus 2.0 programme (Motic Incorporation, Ltd., Hong Kong, China). The tests were carried out using the direct method, marking with the cursor the length of those tracheids to which there was a certainty that they were undamaged. Only a few tracheids were measured on a single preparation. Thus, from one annual ring, 10 to 16 preparations were prepared. Altogether from each species 1260 tracheids of early wood were measured and the same number for late wood.

Statistical analysis was performed using Statistica 10.0 software (Dell, Round Rock, TX, USA). The nonlinear estimation was used for determining the boundary between the juvenile and mature wood zones. The descriptive statistics and one-way analysis of variance (ANOVA) were applied. The values of all properties analyzed in this study were means from measurements taken along the northern and southern rays. All tests were performed at the significance level of $\mathrm{p}<0.05$. 


\section{RESULTS AND DISCUSSION}

The measured tracheid lengths in the function of cambial age in annual rings of Scots pine, European larch, and Norway spruce wood are presented in Fig. 1a through 1c. The cambial age corresponds to the age of the annual ring in which the ring was formed. Each point represents a mean value of 90 measurements of that parameter. The statistical analysis of the recorded results showed that the coefficients of variation for the measured value were comparable and their means for individual species amounted to $17 \%$ for Scots pine, $9 \%$ for European larch, and 7\% for Norway spruce. Numerical values for these coefficients fell within the ranges of coefficients of variation for lengths of prosenchymatic elements in coniferous species (Panshin and De Zeeuw 1980).
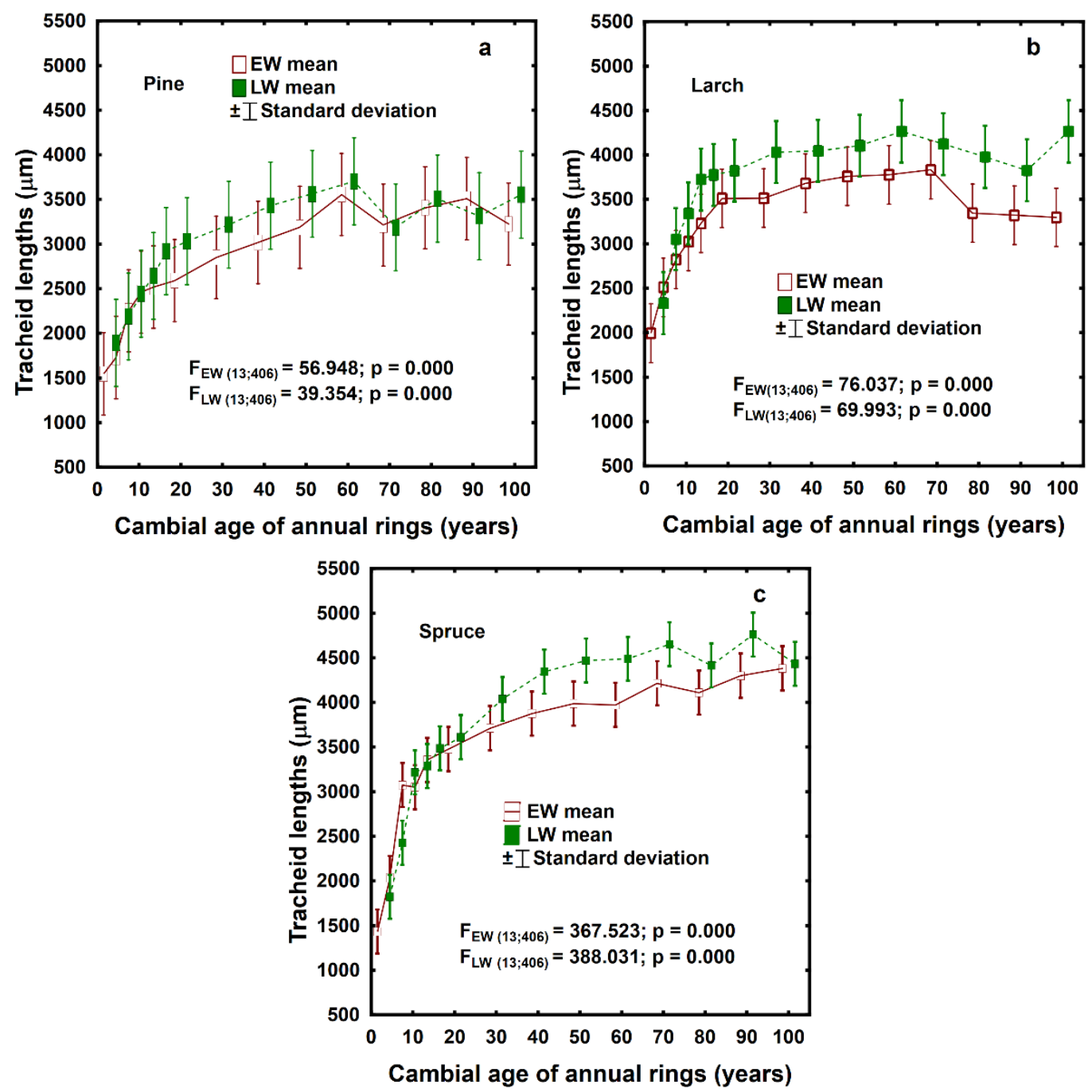

Fig. 1. Relationship between cambial age of annual rings and tracheid lengths (EW - early wood, LW - late wood) in dominant trees of a) Scots pine, b) European larch, and c) Norway spruce

In each analyzed species, tracheids formed in the first part of the vegetation period were shorter than those formed in the summer, irrespective of the location of the annual increment at the stem cross-section. The smallest differences in tracheid lengths between early and late wood were recorded in Norway spruce and Scots pine, as they amounted to 
approximately $9 \%$ and $10 \%$, respectively, while they were the greatest in European larch, reaching approximately 14\%. The confirmation of these differences is the performed ANOVA analysis of variance (Table 1), which shows that for most of the studied annual rings, the differences in the tracheids length of late and early wood were statistically significant $(p<0.05)$. A cursory analysis of data given in Fig. 1a through $1 \mathrm{c}$ indicates that tracheid length initially increased in the direction from the pith towards the bark dynamically, and after reaching a certain value it stabilized at a relatively steady level, showing slight fluctuations in the successive annual increments.

The effects of cambial age on mean tracheid length in the analyzed growth increments in Scots pine, Norway spruce, and European larch wood are presented in Fig. 2. A detailed analysis of variation in the mean tracheid lengths in the investigated species using nonlinear regression made it possible to determine a demarcation line on the ray length of tree between the zone of juvenile and mature wood. The nonlinear estimation module enables to determine the breakpoint $(\mathrm{P})$ of the regression line. The segment regression model is estimated by the software and has a form as follows:

$$
y=\left(a_{1}+b_{1} x\right)(x<=P)+\left(a_{2}+b_{2} x\right)(x>P)
$$

The obtained regression model indicates that it is a two-segment regression (Abdel-Gadir and Krahmer 1993). For the segment corresponding to juvenile wood, the equation takes the form $y_{1}=a_{1}+b_{1} \mathrm{x}$, while for that corresponding to mature wood it is $y_{2}=a_{2}+b_{2} \mathrm{x}$. Parameters of regression equations for tracheid lengths in those zones in the stem crosssection in the analyzed species are given in Table 2 . The boundary between juvenile and mature wood is indicated by the abscissa of the breakpoint $(P)$ of the regression lines. The length of juvenile growth of the examined trees is comparable, as it is 25 annual rings for Scots pine and 29 for European larch, and for Norway spruce. These relationships are also shown graphically in Fig. 2.

Table 1. ANOVA of Early and Late Tracheid Lengths for Annual Rings of Scots Pine, European Larch, and Norway Spruce Wood

\begin{tabular}{|c|c|c|c|c|c|c|c|}
\hline \multirow{4}{*}{$\begin{array}{l}\text { Source of } \\
\text { Variation }\end{array}$} & \multirow{4}{*}{$\begin{array}{c}\text { Cambial } \\
\text { Age of } \\
\text { Annual } \\
\text { Rings }\end{array}$} & \multicolumn{6}{|c|}{ Species } \\
\hline & & \multicolumn{2}{|c|}{ Scots Pine } & \multicolumn{2}{|c|}{ European Larch } & \multicolumn{2}{|c|}{ Norway Spruce } \\
\hline & & \multicolumn{6}{|c|}{ Results of Variance Analysis } \\
\hline & & $F_{(1 ; 58)}$ & $p$ & $F_{(1 ; 58)}$ & $p$ & $F_{(1 ; 58)}$ & $p$ \\
\hline \multirow{14}{*}{$\begin{array}{l}\text { Kind of } \\
\text { Tracheids } \\
\text { (Early, } \\
\text { Late) }\end{array}$} & 3 & 16.989 & 0.000 & 38.767 & 0.000 & 163.357 & 0.000 \\
\hline & 6 & 10.796 & 0.001 & 33.562 & 0.000 & 144.504 & 0.000 \\
\hline & 9 & 2.590 & $0.112^{*}$ & 56.636 & 0.000 & 4.079 & 0.048 \\
\hline & 12 & 2.159 & $0.147^{*}$ & 115.992 & 0.000 & 23.362 & 0.000 \\
\hline & 15 & 11.283 & 0.001 & 123.882 & 0.000 & 5.331 & 0.024 \\
\hline & 20 & 10.5405 & 0.001 & 10.300 & 0.002 & 3.771 & $0.057^{*}$ \\
\hline & 30 & 8.761 & 0.004 & 30.242 & 0.000 & 13.506 & 0.000 \\
\hline & 40 & 13.398 & 0.000 & 17.487 & 0.000 & 32.431 & 0.000 \\
\hline & 50 & 7.974 & 0.006 & 12.261 & 0.000 & 39.178 & 0.000 \\
\hline & 60 & 1.585 & $0.213^{*}$ & 16.141 & 0.000 & 54.668 & 0.000 \\
\hline & 70 & 0.054 & $0.816^{*}$ & 8.902 & 0.004 & 37.531 & 0.000 \\
\hline & 80 & 0.705 & $0.404^{*}$ & 45.415 & 0.000 & 28.389 & 0.000 \\
\hline & 90 & 2.591 & $0.112^{*}$ & 33.689 & 0.000 & 97.978 & 0.000 \\
\hline & 100 & 5.935 & 0.017 & 114.566 & 0.000 & 0.761 & $0.386^{*}$ \\
\hline
\end{tabular}

*Non-significant differences 
In the juvenile zone, the tracheid length increased 2.2-fold in Norway spruce wood, while in Scots pine and European larch wood it was approximately 1.7-fold. By contrast, in the mature wood zone, the length of the tracheids was stabilized at a certain level, showing slight fluctuations. In the mature wood zone, the smallest fluctuations in tracheid lengths were observed in Scots pine and European larch wood, because the ranges in that parameter (i.e., the difference between the longest and shortest tracheids) were practically identical, amounting to $429 \mu \mathrm{m}$ and $447 \mu \mathrm{m}$, respectively. In turn, in Norway spruce wood, this difference was $50 \%$ greater. Moreover, in the last vegetation periods (over the $80^{\text {th }}$ annual ring) in Norway spruce wood, a further increase in tracheid lengths was observed, particularly in late wood, whereas in the other species a downward trend was found. The trend for the tracheid lengths to decrease and an analogous trend also for other properties (e.g., wood density) in old trees was confirmed for many tree species (Pearson and Ross 1984; Zobel and Spraque 1998).

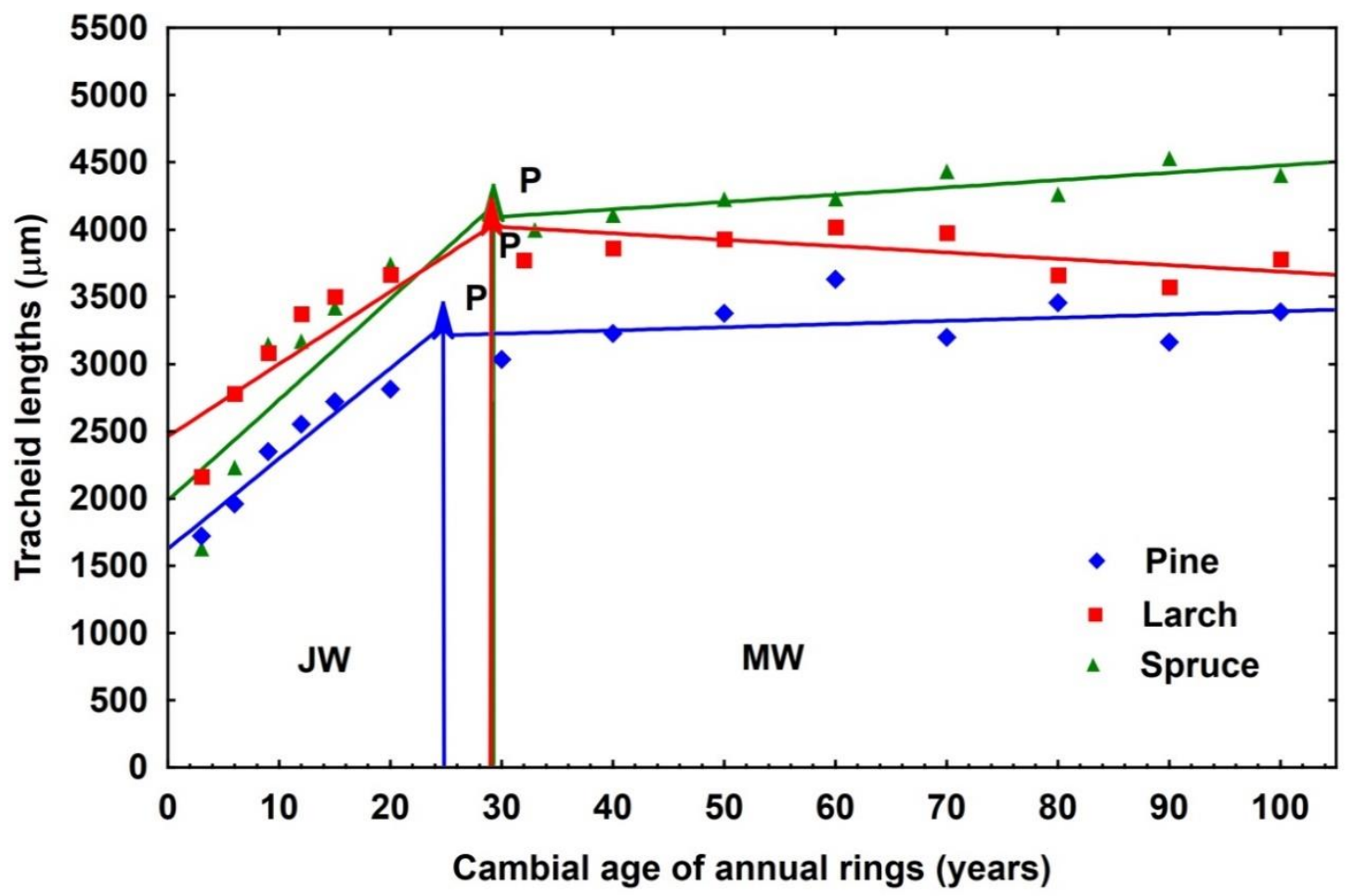

Fig. 2. The effect of cambial age of annual rings on mean tracheid lengths in dominant trees of Scots pine, European larch, and Norway spruce; the demarcation lines between juvenile wood (JW) and mature wood (MW) are marked with vertical lines

Table 2. Parameters of Regression Equations Describing the Relationship Between Tracheid Lengths $(y, \mu \mathrm{m})$ and Cambial Age of Annual Rings ( $x$, years) of Scots Pine, European Larch, and Norway Spruce Wood

\begin{tabular}{|c|c|c|c|}
\hline $\begin{array}{c}\text { Regression } \\
\text { Parameters }\end{array}$ & Scots Pine & European Larch & Norway Spruce \\
\hline $\mathrm{a}_{1}$ & 1623 & 2461 & 1985 \\
\hline $\mathrm{b}_{1}$ & 67.26 & 53.85 & 74.87 \\
\hline $\mathrm{a}_{2}$ & 3155 & 4161 & 3933 \\
\hline $\mathrm{b}_{2}$ & 2.367 & -4.728 & 5.436 \\
\hline $\mathrm{P}$ & 25 & 29 & 29 \\
\hline
\end{tabular}

$\mathrm{P}$ abscissa of breakpoint of the regression lines 
The determined width of the juvenile wood zone in this study was compared with the results of other researchers who conducted research on the wood from dominant trees. It has been found that the width of this zone is similar to that reported by Koizumi et al. (2003), who based on the variability in tracheid lengths of Larix sibirica identified it as 20 annual rings. Similarly, Karlman et al. (2005) assumed the period of juvenile wood formation for pine (Pinus sylvestris) and several larch species (Larix spp.) to be 20 years based on literature data. Fabisiak (2005) and Fabisiak and Moliński (2002a, 2002b) showed that in 45-year-old dominant trees of Douglas fir and Scots pine, the age of transition of juvenile tissue into mature wood was 25 years, while in European larch it was 20 years. Thus, it may be assumed that the period of juvenile wood formation in the analyzed species coming from the same biosocial class was similar.

The mean tracheid lengths in the juvenile and mature wood zones in Scots pine, Norway spruce, and European larch are presented in Fig. 3. When investigating intraspecific variation in the measured parameter in the juvenile and mature wood zones, an ANOVA was conducted, which showed that these differences within the investigated species were statistically significant.

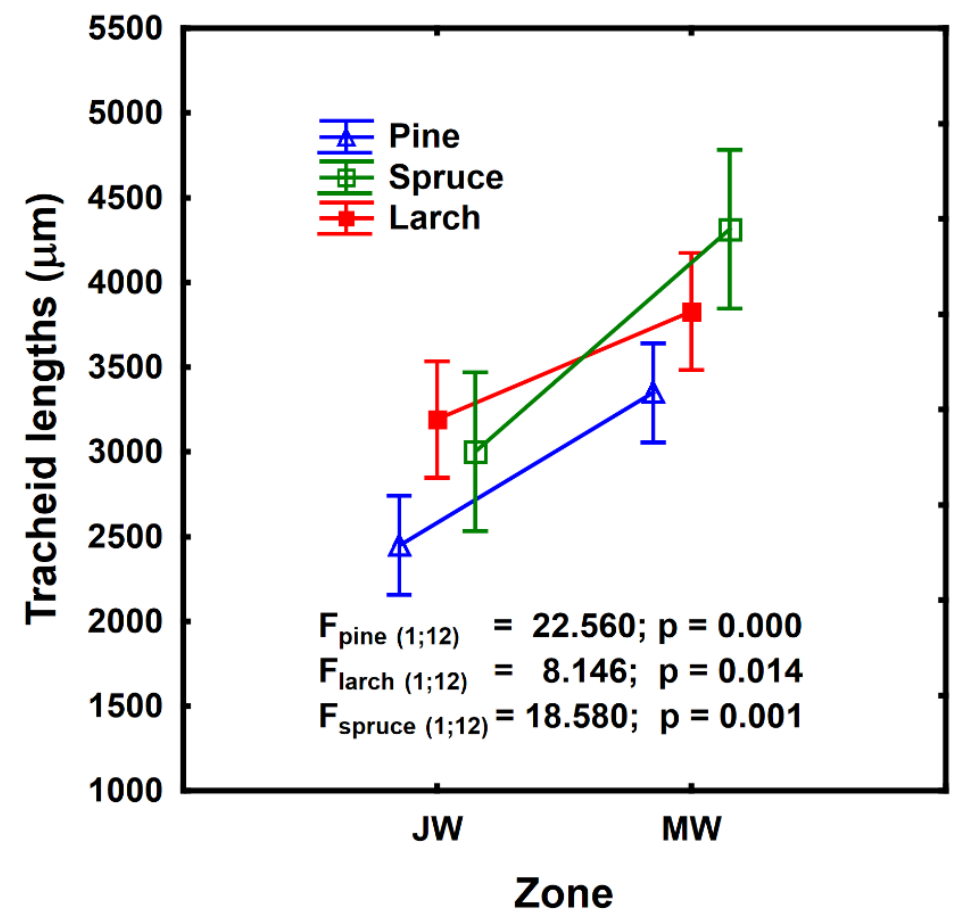

Fig. 3. Mean tracheid lengths in the juvenile (JW) and mature (MW) wood zones in Scots pine, Norway spruce, and European larch wood; vertical bars denote confidence interval of $95 \%$.

In the juvenile wood zone, the mean tracheid lengths were the smallest in Scots pine, and amounted to $2450 \mu \mathrm{m}$. In the juvenile wood zone of Norway spruce wood, tracheids reached $2860 \mu \mathrm{m}$ on average. Tracheids were the longest in European larch wood, with lengths that slightly exceeded $3100 \mu \mathrm{m}$. When comparing the increase in the length of analyzed cells in that zone (JW), it was found that in Scots pine and European larch this value increased approximately $75 \%$, while in Norway spruce it was by as much as $120 \%$. In turn, in the mature wood zone, the longest cells were found in Norway spruce wood, as their average length was $4260 \mu \mathrm{m}$. In European larch wood, this parameter reached 3820 
$\mu \mathrm{m}$. The shortest tracheids in mature wood (similarly as in the pith annual rings) were observed in Scots pine wood. At their mean length in that part of the stem, the cross-section amounted to $3390 \mu \mathrm{m}$.

\section{CONCLUSIONS}

1. In each of the analyzed species, the tracheid length increased in the direction from the pith towards the bark, initially dynamically, and stabilized at a relatively steady level. In the successive annual rings, it showed slight fluctuations up to the stem bark.

2. Tracheids that formed in the first part of the vegetation period were shorter than those formed in the summer, irrespective of the species and the position of the annual ring at the stem cross-section. The smallest differences in the analyzed parameter were recorded in Norway spruce and Scots pine wood, as they amounted to approximately $9 \%$ and $10 \%$, respectively, while they were the greatest in European larch wood, reaching approximately $14 \%$.

3. The period of juvenile wood formation in the examined species was comparable and was identified as 29 annual rings for Norway spruce, and for European larch, and 25 for Scots pine. In that zone, tracheid length increased 2.2-fold in Norway spruce wood, while in Scots pine and European larch wood it was approximately 1.7-fold, in comparison to mature wood of those species.

4. The shortest cells in the juvenile wood zone were found in Scots pine wood (mean tracheid length of $2450 \mu \mathrm{m}$ ), in Norway spruce and European larch wood these cells were longer by $17 \%$ and $24 \%$, respectively, in comparison to Scots pine wood. In the mature wood zone the shortest tracheids were found in Scots pine wood $(3390 \mu \mathrm{m})$, while they were the longest in Norway spruce wood $(4260 \mu \mathrm{m})$.

\section{ACKNOWLEDGEMENTS}

The paper was financed within the framework of Ministry of Science and Higher Education programme 'Regional Initiative of Excellence' in years 2019-2022, Project No. 005/RID/2018/19.

\section{REFERENCES CITED}

Abdel-Gadir, A. Y., and Krahmer, R. L. (1993). "Estimating the age of demarcation of juvenile and mature wood in Douglas-fir," Wood and Fiber Science 25(3), 243-249.

Almeida, T. H., Almeida, D. H., Christoforo, A. L., Chahud, E., Branco, L. A. M. N., and Lahr, F. A. R. (2016). "Density as estimator of strength in compression parallel to the grain in wood," International Journal of Materials Engineering 6(3), 67-71. DOI: 10.5923/j.ijme.20160603.01

Alteyrac, J., Cloutier, A., and Zhang, S. Y. (2006). "Characterization of juvenile wood to mature wood transition age in black spruce (Picea mariana (Mill.) B.S.P.) at different 
stand densities and sampling heights," Wood Science and Technology 40(2), 124-138. DOI: $10.1007 / \mathrm{s} 00226-005-0047-4$

Assmann, E. (1970). The Principles of Forest Yield Study: Studies in the Organic Production, Structure, Increment, and Yield of Forest Stands, Pergamon Press, Oxford.

Bao, F. C., Jiang, Z. H., Jiang, X. M., Lu, X. X., Luo, X. Q., and Zhang, S. Y. (2001). "Differences in wood properties between juvenile wood and mature wood in 10 species grown in China," Wood Science and Technology 35(4), 363-375. DOI: $10.1007 / \mathrm{s} 002260100099$

Bouslimi, B., Koubaa, A., Berge, Y. (2019). "Intra-ring variations and interrelationships for selected wood anatomical and physical properties of Thuja occidentalis L.," Forests 10(4), 339-357. DOI:10.3390/f10040339

Boruszewski, P., Jankowska, A., and Kurowska, A. (2017). "Comparison of the structure of juvenile and mature wood of Larix decidua Mill. from fast-growing plantations in Poland," BioResources 12(1), 1813-1825. DOI: 10.15376/biores.12.1.1813-1825

Cameron, A. D., Gardiner, B. A., Ramsay J., and Drewett, T. A. (2015). "Effect of early release from intense competition within high density natural regeneration on the properties of juvenile and mature wood of 40-year-old Sitka spruce (Picea sitchensis (Bong.) Carr.)," Annals of Forest Science 72(1), 99-107. DOI: 10.1007/s13595-0140402-4

Cloutier, A., Ananias, R. A., Ballerini, A., and Pecho, R. (2007). "Effect of radiata pine juvenile wood on the physical and mechanical properties of oriented strandboard," Holz als Roh- und Werkstoff 65(2), 157-162. DOI: 10.1007/s00107-006-0148-2

Corson, S. R., Flowers, A. G., Morgan, D. G., and Richardson, J. D. (2004). "Paper structure and printability as controlled by the fibrous elements," TAPPI Journal 3(6), 14-18.

Czajka, M., and Fabisiak, E. (2016). "Radial variation of macrostructural parameters and density of wood in dominant trees of coniferous species," Drewno 59(197), 179-187. DOI: 10.12841/wood.1644-3985.C21

Donaldson, L. (2008). "Microfibril angle: Measurement, variation and relationships - A review," IAWA Journal 29(4), 345-386. DOI: 10.1163/22941932-90000192

Downes, G. M., Nyakuengama, J. G., Evans, R., Northway, R., Blakemore, P. H., Dickson, R. L., and Lausberg, M. (2002). "Relationship between wood density, microfibril angle and stiffness in thinned and fertilized Pinus radiata," IAWA Journal 23(3), 253-265. DOI: 10.1163/22941932-90000302

Dumail, J. F., and Castera, P. (1997). "Transverse shrinkage in maritime pine juvenile wood," Wood Science and Technology 31(4), 251-264. DOI: 10.1007/BF00702613

Esteban, L. G., Simón, C., Fernández, F. G., De Palacios, P., Martín-Sampedro, R., Eugenio, M. E., and Hosseinpourpia, R. (2015). "Juvenile and mature wood of Abies pinsapo Boissier: Sorption and thermodynamic properties," Wood Science and Technology 49(4), 725-738. DOI: 10.1007/s00226-015-0730-z

Fabisiak, E. (2005). "Variation of fundamental anatomical elements and wood density of selected tree species," in: Yearbooks of the Agricultural Academy in Poznan, Issue 369, Publishing house of Agricultural Academy in Poznan, Poznan, Poland (in Polish).

Fabisiak, E., and Moliński, W. (2002a). "Variability of the wood basic density and length of tracheids in 45-year larch-fir stand (Larix decidua Mill.)," in: Wood Structure and 
Properties’ 02, J. Kudela, and S. Kurjatko (eds.), Arbora Publishers, Zvolen, Slovakia, pp. 25-28.

Fabisiak, E., and Moliński, W. (2002b). "The density and length of tracheids of Douglas fir (Pseudotsuga menziesii Franco) in relations to the biosocial position of given tree in the stand," Folia Forestalia Polonica Seria B 33, 25-31.

Fabisiak, E., Moliński, W., and Cisowski, M. (2006). "Changes in the MFA at the tangential walls of tracheids in larch wood (Larix decidua Mill.) versus the cambial age of annual rings," Wood Structure and Properties '06, S. Kurjatko, J. Kudela, and R. Lagana (eds.), Arbora Publishers, Zvolen, Slovakia, pp. 39-42.

Fernandes, C., Gaspar, M. J., Pires, J., Silva, M. E., Carvalho, A., Brito, J. L., and Lousada, J. L. (2017). "Within and between-tree variation of wood density components in Pinus sylvestris at five sites in Portugal," European Journal of Wood and Wood Products 75(4), 511-526. DOI: 10.1007/s00107-016-1130-2

Ferreira, A. L., Severo, E. T. D., and Calonego, F. W. (2011). "Determination of fiber length and juvenile and mature wood zones from Hevea brasiliensis trees grown in Brazil," European Journal of Wood and Wood Products 69(4), 659-662. DOI: 10.1007/s00107-010-0510-2

Gapare, W. J., Wu, H. X., and Abarquez, A. (2006). "Genetic control of the time of transition from juvenile to mature wood in Pinus radiata D. Don," Annals of Forest Science 63(8), 871-878. DOI: 10.1051/forest:2006070

Gierlinger, N., and Wimmer, R. (2004). "Radial distribution of heartwood extractives and lignin in mature European larch," Wood and Fiber Science 36(3), 387-394.

Gogoi, B. R., Sharma, M., and Sharma, C. L. (2018). "Tracheid length variation in Pinus kesiya Royle Ex Gord. as affected by age, distance from pith, growth rate and ring width," Journal of Tree Sciences 37(2), 55-61. DOI: 10.5958/2455-

7129.2018.00017.1

Hayatgheibi, H., Forsberg, N. E. G., Lundqvist, S.-O., Mörling, T., Mellerowicz, E. J., Karlsson, B., Wu, H. X., and García-Gil, M. R. (2018). "Genetic control of transition from juvenile to mature wood with respect to microfibril angle in Norway spruce (Picea abies) and lodgepole pine (Pinus contorta)," Canadian Journal of Forest Research 48(11), 1358-1365. DOI: 10.1139/cjfr-2018-0140

Helińska-Raczkowska, L., and Fabisiak, E. (1991). "Radial variation and growth rate in the length of axial elements of sessile oak wood," IAWA Bulletin 12(3), 257-262.

Helińska-Raczkowska, L., and Fabisiak, E. (1999). "Radial variation of earlywood vessel lumen diameter as an indicator of the juvenile growth period in ash (Fraxinus excelsior L.)," Holz als Roh- und Werkstoff 57(4), 283-286.

Ivković, M., Gapare, W. J., Abarquez, A., Ilic, J., Powell, M. B., and Wu, H. X. (2009). "Prediction of wood stiffness, strength, and shrinkage in juvenile wood of radiata pine," Wood Science and Technology 43, 237-257. DOI: 10.1007/s00226-008-0232-3

Karlman, L., Mörling, T., and Martinsson, O. (2005). "Wood density, annual ring width and latewood content in larch and Scots pine," Eurasian Journal of Forest Research $8(2), 91-96$.

Kijidani, Y., Kawasaki, Y., Matsuda, D., Nakazono, F., Hayakawa, M., Mutaguchi, H., and Sakagami, H. (2014). "Tree heights in the ring-formed years affect microfibril angles in the rings from juvenile to mature wood at breast height in hinoki trees (Chamaecyparis obtusa)," Journal of Wood Science 60(6), 381-388. DOI: 10.1007/s10086-014-1426-y 
Koizumi, A., Takata, K., Yamashita, K., and Nakada, R. (2003). "Anatomical characteristics and mechanical properties of Larix sibirica grown in south-central Siberia," IAWA Journal 24(4), 355-370. DOI: 10.1163/22941932-90000341

Koubaa, A., Isabel, N., Zhang, S. Y., Beaulieu, J., and Bousquet, J. (2005). “Transition from juvenile to mature wood in black spruce (Picea mariana (Mill.) B.S.P.)," Wood and Fiber Science 37(3), 445-455.

Kuprevicius, A., Auty, D., Achim, A., and Caspersen, J. P. (2013). "Quantifying the influence of live crown ratio on the mechanical properties of clear wood," Forestry 86, 361-369. DOI 10.1093/forestry/cpt006

Larson, P. R. (1962). “A biological approach to wood quality," TAPPI 45, 443-448.

Larson, P. R. (1994). The Vascular Cambium. Development and Structure, SpringerVerlag, Berlin.

Mansfield, S. D., Parish, R., Goudie, J. W., Kang, K.-Y., and Ott, P. (2007). "The effects of crown ratio on the transition from juvenile to mature wood production in lodgepole pine in western Canada," Can. J. For. Res. 37, 1450-1459.

DOI:10.1139/X06-299

Mott, L., Groom, L., and Shaler, S. (2002). "Mechanical properties of individual southern pine fibers. Part 2. Comparison of earlywood and latewood fibers with respect to tree height and juvenility," Wood and Fiber Science 34(2), 221-237.

Mvolo, C. S., Koubaa, A., Beaulieu, J., Cloutier, A., and Mazerolle, M. J. (2015a). "Variation in wood quality in white spruce (Picea glauca (Moench) Voss). Part I. Defining the juvenile-mature wood transition based on tracheid length," Forests 6 , 183-202. DOI 10.3390/f6010183

Mvolo, C. S., Koubaa, A., Defo, M., Beaulieu, J., Yemele, M. C., and Cloutier, A. (2015b). "Prediction of tracheid length and diameter in white spruce (Picea glauca)," IAWA Journal 36(2), 186-207. DOI 10.1163/22941932-00000095

Palermo, G. P. M., Latorraca, J. V. F., Carvalho, A. M., Calonego, F. W., and Severo, E. T. D. (2015). "Anatomical properties of Eucalyptus grandis wood and transition age between the juvenile and mature woods," European Journal of Wood and Woods Products 73(6), 775-780. DOI: 10.1007/s00107-015-0947-4

Panshin, A. J., and De Zeeuw, C. (1980). Textbook of Wood Technology, McGraw-Hill, New York, NY, USA.

Passialis, C., and Kiriazakos, A. (2004). "Juvenile and mature wood properties of naturally-grown fir trees," Holz als Roh-und Werkstoff 62(6), 476-478. DOI: 10.1007/s00107-004-0525-7

Pearson, R. G., and Ross, B. E. (1984). "Growth rate and bending properties of selected loblolly pines," Wood and Fiber Science 16(1), 37-47.

Rowell, R. M., Petersen, R., Han, J. S., Rowell, J. S., and Tshabalala, M. A. (2005). "Cell wall chemistry," in: Handbook of Wood Chemistry and Wood Composites, R. M. Rowell (ed.), CRC Press, Boca Raton, FL, USA, pp. 35-74

Semen, E., Kuo, M., Su, Y. C., Hall, R. B., and Stokke, D. D. (2001). "Physical properties of kraft pulp from four-year-old aspen hybrids and crosses," Wood and Fiber Science 33(1), 140-147.

Severo, E. T. D., Calonego, F. W., and Sansígolo, C. A. (2012) "Physical and chemical changes in juvenile and mature woods of Pinus elliottii var. elliottii by thermal modification," European Journal of Wood and Wood Products 70(5), 741-747. DOI: 10.1007/s00107-012-0611-1 
Wang, M., and Stewart, J. D. (2012). "Determining the transition from juvenile to mature wood microfibril angle in lodgepole pine: A comparison of six different two-segment models," Annals of Forest Science 69(8), 927-937. DOI: 10.1007/s13595-012-0226-Z

Wu, G., Zhu, E., Zhong, Y., Gong, Y., and Ren, H. (2018). "Development and investigation of a hybrid built-up column made of small diameter logs originating from juvenile trees," Journal of Wood Science 64(4), 356-363. DOI: 10.1007/s10086017-1689-1

Yang, X., Liu, X., Shang, L., Ma, J., Tian, G., and Yang, S. (2016). "Variation of tensile properties of single fibres of Dendrocalamus farinosus bamboo," BioResources 11(1), 1609-1619. DOI: 10.15376/biores.11.1.1609-1619

Zhu, J., Nakano, T., and Hirakawa, Y. (2000). "Effect of radial growth rate on selected indices for juvenile and mature wood of the Japanese larch," Journal of Wood Science 46(6), 417-422. DOI: 10.1007/BF00765798

Zobel, B. J., and van Buijtenen, J. P. (1989). Wood Variation - Its Causes and Control, Springer-Verlag, Berlin.

Zobel, B. J., and Jett, J. B. (1995). Genetics of Wood Production, Springer-Verlag, Berlin, Heidelberg, Germany.

Zobel, B. J., and Sprague, J. R. (1998). Juvenile Wood in Forest Trees, Springer Verlag, Berlin, Heidelberg, Germany.

Article submitted: June 29, 2019; Peer review completed: October 26, 2019;

Revised version received and accepted: July 26, 2020; Published: August 5, 2020.

DOI: 10.15376/biores.15.4.7330-7341 